\title{
PENGUASAAN MODEL PENILAIAN HASIL BELAJAR DALAM MERAIH MUTU SEKOLAH OLEH KEPALA SEKOLAH MELALUI SUPERVISI AKADEMIK DI SMPN 41 MEDAN
}

\author{
Oleh: \\ Lukman Pardede ${ }^{1)}$ \\ dan Dewi Lestari Pardede ${ }^{2)}$ \\ Universitas Darma Agung, Medan \\ dan Sekolah tinggi ilmu ekonomi indonesia (STINDO) ${ }^{1,2)}$ \\ E-mail: \\ pardedelukman@yahoo.com ${ }^{1)}$ \\ Pardede_dewilestari@yahoo.co.id ${ }^{2)}$
}

\begin{abstract}
This study aims at determining the extent of the application of academic supervision in improving the performance of school principals in applying the learning outcomes assessment model at SMPN 41 Medan. Assessment consists of external assessments and internal assessments. External assessments are assessments made by other parties who do not carry out the learning process. External assessments are carried out by an institution, both domestic and foreign, intended among other things to control quality. While internal assessments are assessments planned and carried out by the teacher during the learning process. Class assessment is part of an internal assessment (internal assessment) to determine student learning outcomes towards mastery of competencies taught by the teacher. The aim is to assess the level of achievement of student competencies that are carried out when learning takes place and the end of learning. The assessment of student learning outcomes is carried out by the teacher to monitor the process, progress, development of student learning outcomes in accordance with their potential and expected abilities on an ongoing basis. Assessment can also provide feedback to teachers in order to improve planning and learning processes. In this surveillance action research carried out in 3 cycles, the results of the actions taken are proven to improve the quality of schools by achieving ideal standards. From $64.25 \%$ in Cycle 1, it can be increased to $73.75 \%$ in Cycle II, and in the third cycle to $83.25 \%$ and has met the ideal standard.
\end{abstract}

Keywords: learning outcomes assessment model, school quality, school principal, supervision

\begin{abstract}
ABSTRAK
Tujuan penelitian adalah untuk mengetahui sejauh mana penerapan supervisi akademik dalam meningkatkan kinerja kepala sekolah dalam menerapkan model penilaian hasil belajar di SMPN 41 Medan. Penilaian terdiri atas penilaian eksternal dan penilaian internal. Penilaian eksternal merupakan penilaian yang dilakukan oleh pihak lain yang tidak melaksanakan proses pembelajaran. Penilaian eksternal dilakukan oleh suatu lembaga, baik dalam maupun luar negeri dimaksudkan antara lain untuk pengendali mutu. Sedangkan penilaian internal adalah penilaian yang direncanakan dan dilakukan oleh guru pada saat proses pembelajaran berlangsung. Penilaian kelas merupakan bagian dari penilaian internal (internal assessment) untuk mengetahui hasil belajar peserta didik terhadap penguasaan kompetensi yang diajarkan oleh guru. Tujuannya adalah untuk menilai tingkat pencapaian kompetensi peserta didik yang dilaksanakan pada saat pembelajaran berlangsung dan akhir pembelajaran. Penilaian hasil belajar peserta didik dilakukan oleh guru untuk memantau proses, kemajuan, perkembangan hasil belajar peserta didik sesuai dengan potensi yang dimiliki dan kemampuan yang diharapkan secara berkesinambungan. Penilaian juga dapat memberikan umpan balik kepada guru agar dapat menyempurnakan perencanaan dan proses pembelajaran. Dalam penelitian tindakan kepengawasan ini dilakukan dalam 3 siklus, dari hasil tindakan yang dilakukan terbukti dapat meningkatkan mutu sekolah dengan mencapai standar ideal. Dari $64,25 \%$ pada Siklus 1, dapat meningkat menjadi $73,75 \%$ pada siklus II, dan siklus ke 3 menjadi $83,25 \%$ dan sudah memenuhi standar ideal.
\end{abstract}

Kata Kunci : model penilaian hasil belajar, mutu sekolah, kepala sekolah, suvervisi 


\section{PENDAHULUAN}

Penilaian kelas merupakan bagian dari penilaian internal (internal assessment) untuk mengetahui hasil belajar peserta didik terhadap penguasaan kompetensi yang diajarkan oleh guru. Tujuannya adalah untuk menilai tingkat pencapaian kompetensi peserta didik yang dilaksanakan pada saat pembelajaran berlangsung dan akhir pembelajaran.

Penilaian hasil belajar peserta didik dilakukan oleh guru untuk memantau proses, kemajuan, perkembangan hasil belajar peserta didik sesuai dengan potensi yang dimiliki dan kemampuan yang diharapkan secara berkesinambungan. Penilaian juga dapat memberikan umpan balik kepada guru agar dapat menyempurnakan perencanaan dan proses pembelajaran.

Penilaian hasil belajar pada sebuah sekolah merupakan suatu kegiatan sekolah yang berkaitan dengan pengambilan keputusan tentang pencapaian kompetensi atau hasil belajar peserta didik yang mengikuti proses pembelajaran. Untuk itu, diperlukan data sebagai informasi yang diandalkan sebagai dasar pengambilan keputusan.

Data yang diperoleh sekolah selama pembelajaran berlangsung dijaring dan dikumpulkan melalui prosedur dan alat penilaian yang sesuai dengan kompetensi atau indikator yang akan dinilai. Dari proses ini, diperoleh potret/profil kemampuan peserta didik dalam mencapai sejumlah standar kompetensi dan kompetensi dasar yang dirumuskan dalam Kurikulum Tingkat Satuan Pendidikan masing-masing.

Penilaian hasil belajar baik formal maupun informal diadakan dalam suasana yang menyenangkan, sehingga memungkinkan peserta didik menunjukkan apa yang dipahami dan mampu dikerjakannya. Hasil belajar seorang peserta didik dalam periode waktu tertentu dibandingkan dengan hasil yang dimiliki peserta didik tersebut sebelumnya dan tidak dianjurkan untuk dibandingkan dengan peserta didik lainnya. Dengan demikian peserta didik tidak merasa dihakimi oleh sekolah tetapi dibantu untuk mencapai kompetensi atau indikator yang diharapkan.

Uraian tersebut di atas tentunya tidak akan bisa terlaksana dengan baik jika kepala seklah tidak mampu membina guru di sekolah dalam memberikan penilaian yang obyektif. Selain itu masih ada kepala sekolah yang memberikan penilaian tidak sesuai dengan kompetensi dan indikator yang telah dibuat oleh sekolah, oleh karena itu peran pengawas dalam membina kepala sekolah melakukan penilaian hasil belajar sangat penting dalam upaya peningkatan mutu pendidikan, khususnya di tingkat sekolah menengah (SMP), mulai dari jenis penilaian, teknik penilaian, model penilaian, maupun alat ukur yang digunakan dalam penilaian. Kepala sekolah perlu dibina melalui supervisi pengawas agar kinerja kepala sekolah dalam menerapkan model penilaian dapat ditingkatkan.

\section{TINJAUAN PUSTAKA \\ Pengertian Penilaian Hasil Belajar}

$$
\text { Penilaian hasil belajar }
$$
merupakan suatu proses yang dilakukan melalui langkah-langkah perencanaan, penyusunan alat penilaian, pengumpulan informasi melalui sejumlah bukti yang menunjukkan pencapaian hasil belajar peserta didik, pengolahan, dan penggunaan informasi tentang hasil belajar peserta didik. Penilaian hasil belajar dilaksanakan 
melalui berbagai teknik/cara, seperti penilaian unjuk kerja (performance), penilaian sikap, penilaian tertulis (paper and pencil test), penilaian proyek, penilaian produk, penilaian melalui kumpulan hasil kerja/karya peserta didik (portfolio), dan penilaian diri.

Penilaian hasil belajar baik formal maupun informal diadakan dalam suasana yang menyenangkan, sehingga memungkinkan peserta didik menunjukkan apa yang dipahami dan mampu dikerjakannya. Hasil belajar seorang peserta didik dalam periode waktu tertentu dibandingkan dengan hasil yang dimiliki peserta didik tersebut sebelumnya dan tidak dianjurkan untuk dibandingkan dengan peserta didik lainnya. Dengan demikian peserta didik tidak merasa dihakimi oleh guru tetapi dibantu untuk mencapai kompetensi atau indikator yang diharapkan.

\section{Fungsi Penilaian Hasil Belajar}

Penilaian kelas memiliki fungsi sebagai berikut :

a) Menggambarkan sejauhmana seorang peserta didik telah menguasai suatu kompetensi.

b) Mengevaluasi hasil belajar peserta didik dalam rangka membantu peserta didik memahami dirinya, membuat keputusan tentang langkah berikutnya, baik untuk pemilihan program, pengembangan kepribadian maupun untuk penjurusan (sebagai bimbingan).

c) Menemukan kesulitan belajar dan kemungkinan prestasi yang bisa dikembangkan peserta didik dan sebagai alat diagnosis yang membantu guru menentukan apakah seseorang perlu mengikuti remedial atau pengayaan. d) Menemukan kelemahan dan kekurangan proses pembelajaran yang sedang berlangsung guna perbaikan proses pembelajaran berikutnya.

e) Sebagai kontrol bagi guru dan sekolah tentang kemajuan perkembangan peserta didik.

\section{Prinsip-Prinsip Penilaian Hasil Belajar}

a) Validitas

Validitas berarti menilai apa yang seharusnya dinilai dengan menggunakan alat yang sesuai untuk mengukur kompetensi. Dalam mata pelajaran pendidikan jasmani, olahraga dan kesehatan, misalnya kompetensi "mempraktikkan gerak dasar jalan...", maka penilaian valid apabila menggunakan penilaian unjuk kerja. Jika menggunakan tes tertulis maka penilaian tidak valid.

\section{b) Reliabilitas}

Reliabilitas berkaitan dengan konsistensi (keajegan) hasil penilaian. Penilaian yang reliable (ajeg) memungkinkan perbandingan ynag reliable dan menjamin konsistensi. Misal, guru menilai dengan unjuk kerja, penilaian akan reliabel jika hasil yang diperoleh itu cenderung sama bila unjuk kerja itu dilakukan lagi dengan kondisi yang relatif sama. Untuk menjamin penilaian yang reliabel petunjuk pelaksanaan unjuk kerja dan penskorannya harus jelas.

\section{c) Menyeluruh}

Penilaian harus dilakukan secara menyeluruh mencakup seluruh domain yang tertuang pada setiap kompetensi dasar. Penilaian harus menggunakan beragam cara dan alat untuk menilai beragam kompetensi peserta didik, sehingga tergambar profil kompetensi peserta didik. 
d) Berkesinambungan

Penilaian dilakukan secara terencana, bertahap dan terus menerus untuk memperoleh gambaran pencapaian kompetensi peserta didik dalam kurun waktu tertentu.

\section{e) Obyektif}

Penilaian harus dilaksanakan secara obyektif. Untuk itu, penilaian harus adil, terencana, dan menerapkan kriteria yang jelas dalam pemberian skor.

\section{f) Mendidik}

Proses dan hasil penilaian dapat dijadikan dasar untuk memotivasi, memperbaiki proses pembelajaran bagi guru, meningkatkan kualitas belajar dan membina peserta didik agar tumbuh dan berkembang secara optimal.

\section{Supervisi Akademik Pengawas}

Supervisi akademik adalah serangkaian kegiatan membantu kepala sekolah mengembangkan kemampuannya mengelola proses pembelajaran untuk mencapai tujuan pembelajaran (Daresh, 1989, Glickman, et al; 2007). Supervisi akademik tidak terlepas dari penilaian kinerja kepala sekolah dalam mengelola pembelajaran. Sergiovanni (1987) dan Pardede L (2019) menegaskan bahwa refleksi praktis penilaian kinerja kepala sekolah dalam supervisi akademik adalah melihat kondisi nyata kinerja kepala sekolah untuk menjawab pertanyaanpertanyaan, misalnya apa yang sebenarnya terjadi di sekolah? Apa yang sebenarnya dilakukan oleh guru dan siswa di dalam kelas? Aktivitasaktivitas mana dari keseluruhan aktivitas di dalam sekolah itu yang bermakna bagi guru dan murid? Apa yang telah dilakukan oleh kepala sekolah dalam mencapai tujuan akademik? Apa kelebihan dan kekurangan kepala sekolah dan bagaimana cara mengembangkannya? Berdasarkan jawaban terhadap pertanyaan-pertanyaan ini akan diperoleh informasi mengenai kemampuan kepala sekolah dalam mengelola dan mengembangkan penilaian hasil belajar. Namun satu hal yang perlu ditegaskan di sini, bahwa setelah melakukan penilaian kinerja berarti selesailah pelaksanaan supervisi akademik melainkan harus dilanjutkan dengan tindak lanjutnya berupa pembuatan program supervisi akademik dan melaksanakannya dengan sebaikbaiknya.

a. Tujuan Supervisi Akademik

Tujuan supervisi akademik adalah :

(1) membantu guru mengembangkan kompetensinya,

(2) mengembangkan kurikulum,

(3) mengembangkan kelompok kerja guru.

b. Prinsip-prinsip Supervisi Akademik

(1) Praktis, artinya mudah dikerjakan sesuai kondisi sekolah.

(2) Sistematis, artinya dikembangkan sesuai perencanaan program supervisi yang matang dan tujuan pembelajaran.

(3) Objektif, artinya masukan sesuai aspek-aspek instrumen.

(4) Realistis, artinya berdasarkan kenyataan sebenarnya.

(5) Antisipatif, artinya mampu menghadapi masalahmasalah yang mungkin akan terjadi.

(6) Konstruktif, artinya mengembangkan kreativitas dan inovasi guru dalam mengembangkan proses pembelajaran. 
(7) Kooperatif, artinya ada kerja sama yang baik antara supervisor dan guru dalam mengembangkan pembelajaran.

(8) Kekeluargaan, artinya mempertimbangkan saling asah, asih, dan asuh dalam mengembangkan pembelajaran.

(9) Demokratis, artinya supervisor tidak boleh mendominasi pelaksanaan supervisi akademik.

(10) Aktif, artinya guru dan supervisor harus aktif berpartisipasi.

(11) Humanis, artinya mampu menciptakan hubungan kemanusiaan yang harmonis, terbuka, jujur, ajeg, sabar, antusias, dan penuh humor (Dodd, 1972).

(12) Berkesinambungan (supervisi akademik dilakukan secara teratur dan berkelanjutan oleh Kepala SMP/MTS).

(13) Terpadu, artinya menyatu dengan pendidikan.

(14) Komprehensif, artinya memenuhi ketiga tujuan supervisi akademik di atas.

\section{Peningkatan Capaian Mutu Sekolah}

1. Pengertian Mutu Sekolah

Mutu adalah baik buruknya suatu kualitas, taraf atau derajat dari kecerdasan, kepandaian. Dalam kamus Bahasa Inggris Mutu adalah Mutiara; kualitas, tingkat/taraf, sedangkan bermutu adalah kualitas tinggi; pintar.

2. Pemecahan Masalah Mutu Sekolah Meskipun untuk tiap-tiap jenis dan jenjang pendidikan masing-masing memiliki kekhususan, namun pada dasarnya pemecahan masalah mutu sekolah sasarannya adalah pada perbaikan kualitas komponen pendidikan (utamanya komponen masukan mentah untuk jenjang pendidikan menengah dan tinggi, dan komponen masukan instrumental) serta mobilitas komponen-komponen tersebut. Upaya tersebut pada gilirannya diharapkan dapat meningkatkan kualitas peserta didik, yang akhirnya dapat meningkatkan hasil pendidikan.

Upaya pemecahan masalah mutu pendidikan dalam garis besarnya meliputi hal-hal yang bersifat fisik dan perangkat lunak, persoalan, dan manajemen sebagai berikut :

a. Seleksi yang lebih rasional terhadap masukan mentah, khususnya untuk sekolah menengah dan perguruan tinggi.

b. Pengembangan kemampuan untuk tenaga kependidikan melalui studi lanjut, misalnya berupa Pelatihan, Penataran, Seminar, Kegiatan-kegiatan kelompok studi seperti PKG, dan MHMP.

c. Penyempurnaan kurikulum, misalnya dengan memberi materi yang lebih esensial dan mengandung muatan lokal, metode yang menantang dan menggairahkan belajar, dan melaksanakan evaluasi yang beracuan PAP.

d. Pengembangan prasarana yang menciptakan lingkungan yang tentram untuk belajar.

e. Penyempurnaan sarana belajar seperti buku paket, media pembelajaran dan peralatan laboratorium. 
f. Peningkatan administrasi manajemen khususnya yang mengenai anggaran.

g. Kegiatan pengendalian mutu yang berupa kegiatan-kegiatan

1) Laporan penyelenggara pendidikan oleh semua lembaga pendidikan.

2) Supervisi dan monitoring pendidikan oleh penilik dan pengawas.

3) Sistem Ujian Nasional/Negara seperti UAN dan UAS.

4) Akreditasi terhadap lembaga pendidikan untuk menetapkan status suatu lembaga.

\section{METODE PELAKSANAAN}

Penelitian tindakan pengawasan dilaksanakan di SMPN 41 Medan. Dengan Metode tindakan atau PTK. Pengolahan data dengan metode kualitatif dan kuantitatif. Objek penelitiannya adalah Kepala Sekolah.

Model penelitian dilaksanakan dengan tindakan kepengawasan dengan proses melakukan tindakan awal, siklus 1, siklus 2, dan siklus 3. Setiap siklus penulis melakukan tahapan perencanaan, tindakan, observasi dan refleksi.

Dalam penelitian Tindakan Kepengawasan ini variabel yang akan diteliti adalah peningkatan kinerja kepala sekolah dalam menerapkan model penilaian hasil belajar, pembinaan pengawas melalui supervisi akademik di SMP binaan di Kota Medan tahun pelajaran 2019/2020.

Variabel tersebut dapat dituliskan kembali sebagai berikut:

Variabel Harapan : Peningkatan kinerja kepala sekolah dalam menerapkan model

belajar. penilaian hasil

Variabel Tindakan : Pembinaan

Pengawas melalui supervisi akademik.

Adapun indikator yang akan diteliti dalam variabel harapan terdiri dari :

1. Kemampuan dan potensi kinerja kepala SMP

2. Kemampuan dalam meningkatkan kinerja kepala sekolah

3. Kemampuan menguasai materi bimbingan dan pembinaan pengawas

4. Kemampuan meningkatkan kinerja kepala sekolah

Sedangkan variabel tindakan memiliki indikator sebagai berikut :

1. Tingkat kualitas perencanaan

2. Kualitas perangkat observasi

3. Kualitas operasional tindakan

4. Kesesuaian perencanaan dengan tindakan kepengawasan

5. Kesesuaian materi pembinaan dan bimbingan yang diberikan pengawas

6. Tingkat efektifitas pembinaan dalam meningkatkan kinerja kepala SMP

7. Kemampuan pembinaan pengawas dalam meningkatkan kinerja kepala SMP. 
Jadwal Pelaksanaan Penelitian

Jadwal Pelaksanaan Penelitian

\begin{tabular}{|c|c|c|c|c|c|c|c|c|}
\hline \multirow{3}{*}{ No } & \multirow{3}{*}{ Uraian Kegiatan } & \multicolumn{6}{|c|}{ Bulan } & \multirow{3}{*}{ Keterangan } \\
\hline & & \multicolumn{3}{|c|}{ Januari } & \multicolumn{3}{|c|}{ Februari } & \\
\hline & & 1 & 2 & 3 & 1 & 2 & 3 & \\
\hline 1. & Persiapan dan koordinasi & $\mathrm{X}$ & & & & & & \\
\hline \multirow[t]{5}{*}{2.} & Siklus I & & & & & & & \\
\hline & Perencanaan & & $\mathrm{X}$ & & & & & \\
\hline & Tindakan & & $\mathrm{X}$ & & & & & \\
\hline & Observasi & & $\mathrm{X}$ & & & & & \\
\hline & Evaluasi & & & $\mathrm{X}$ & & & & \\
\hline \multirow[t]{5}{*}{3.} & Siklus II & & & & & & & \\
\hline & Perencanaan & & & $\mathrm{X}$ & & & & \\
\hline & Tindakan & & & $\mathrm{X}$ & & & & \\
\hline & Observasi & & & $\mathrm{X}$ & & & & \\
\hline & Evaluasi & & & & $\mathrm{X}$ & & & \\
\hline \multirow[t]{5}{*}{4.} & Siklus III & & & & $\mathrm{X}$ & & & \\
\hline & Perencanaan & & & & $\mathrm{X}$ & & & \\
\hline & Tindakan & & & & $\mathrm{X}$ & & & \\
\hline & Observasi & & & & $\mathrm{X}$ & & & \\
\hline & Evaluasi & & & & & $\mathrm{X}$ & & \\
\hline 5. & Analisa Data & & & & & $\mathrm{X}$ & & \\
\hline 6. & Penyusunan Draft Laporan & & & & & $\mathrm{X}$ & & \\
\hline 7. & Penyusunan Laporan Akhir & & & & & & $\mathrm{X}$ & \\
\hline
\end{tabular}

\section{Rancang Tindakan}

Rancangan tindakan dilakukan sebagai berikut:

1. Tindakan dilaksanakan dalam 3 siklus.

2. Kegiatan dilaksanakan dalam semester ganjil tahun pelajaran 2019/2020.

3. Lama penelitian 4 minggu efektif dilaksanakan mulai bulan Januari Pebruari 2020.
Dalam pelaksanaan tindakan, rancangan dilakukan dalam 3 siklus yang meliputi : (a) perencanaan, (2) tindakan, (3) pengamatan, (4) refleksi.

Rancangan Penelitian Tindakan Kepengawasan (PTKp) menurut Kemmis dan Mc. Taggar (Depdiknas, 2000) adalah seperti gambar berikut : 


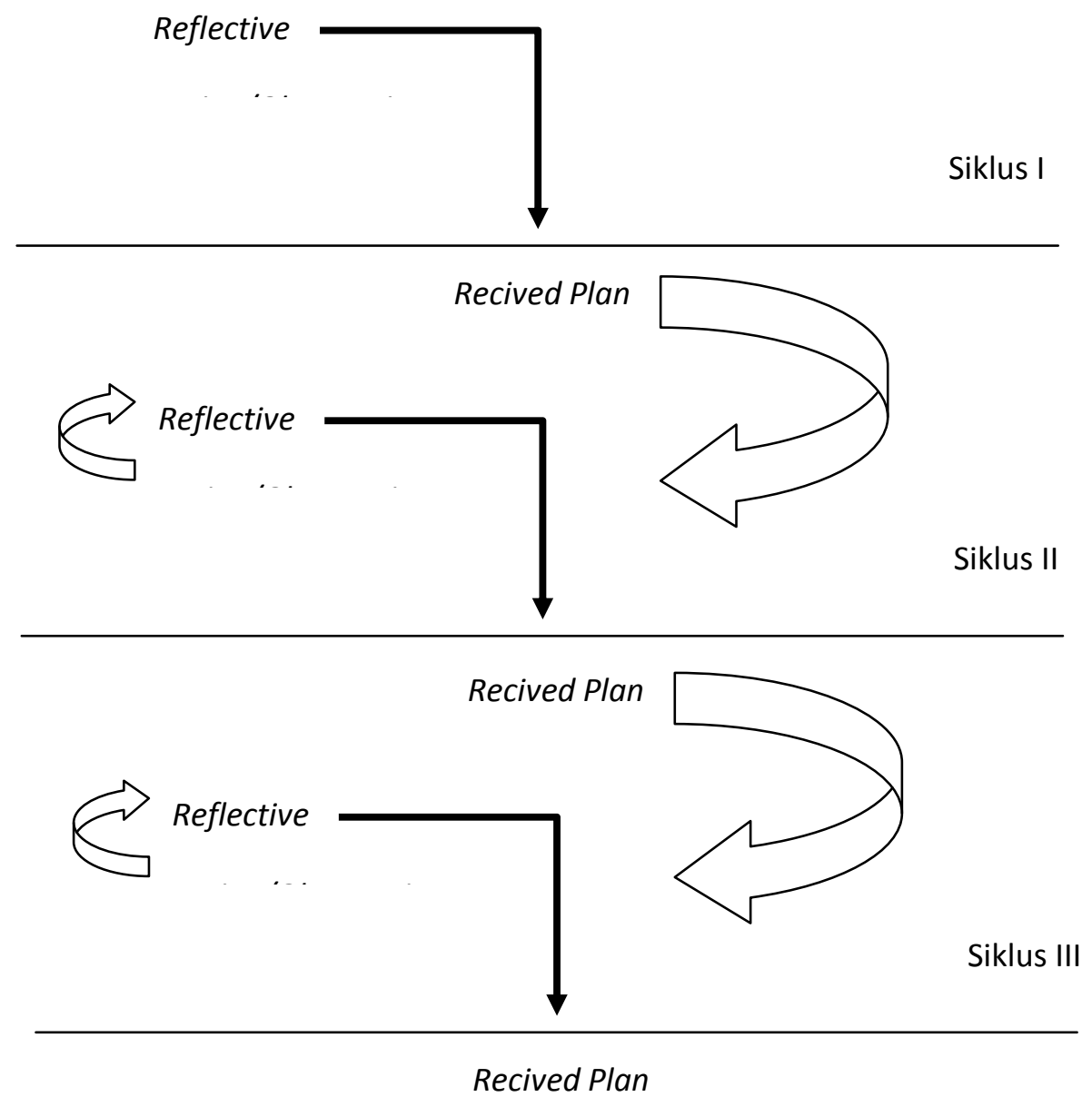

Gambar 3.1. Alur Penelitian Tindakan Kepengawasan

1. Rencana (Plan) : adalah rencana tindakan apa yang akan dilakukan untuk memperbaiki, meningkatkan atau perubahan perilaku dan sikap sebagai solusi.

2. Tindakan (Action) : adalah apa yang dilakukan oleh peneliti/pengawas sebagai upaya perbaikan, peningkatan atau perubahan yang diinginkan.

3. Observasi (Observation) : adalah mengamati atas hasil atau dampak dari tindakan yang dilaksanakan atau dikenakan terhadap kepala sekolah.

4. Refleksi (reflection) : adalah peneliti mengkaji, melihat, dan mempertimbangkan atas hasil atau dampak dari tindakan dari pelbagai kriteria.

5. Revisi (recived plan) : adalah berdasarkan dari hasil refleksi ini, peneliti melakukan revisi terhadap rencana awal. 


\section{HASIL dan PEMBAHASAN}

\section{Hasil Penelitian}

Hasil tindakan penelitian dan aksi kepala sekolah dan pengawas pada tindakan penelitian dalam penyempurnaan indikator penelitian akan disajikan dalam hasil perolehan setelah tindakan.

\section{Deskripsi Hasil \\ Tindakan Awal}

Penelitian ini menggunakan model pembinaan kepala sekolah melalui supervisi akademik. Tujuan yang diharapkan pada pertemuan pertama dalam pembinaan pengawas melalui supervisi akademik ini adalah peningkatan kinerja keala sekolah dalam menerapkan model penilaian hasil belajar.

Agar tercapai tujuan di atas, peneliti yang bertindak sebagai pembimbing dengan melakukan langkah-langkah sebagai berikut :

a) Menyusun instrumen pembinaan

b) Menyusun instrumen monitoring

c) Sosialisasi kepada kepala sekolah

d) Melaksanakan tindakan dalam kepengawasan

e) Melakukan refleksi

f) Menyusun strategi pembinaan pada siklus kedua berdasar refleksi siklus pertama

g) Melaksanakan pembinaan pada siklus kedua

h) Melakukan observasi

i) Melakukan refleksi pada siklus kedua

j) Menyusun strategi pembinaan pada siklus ketiga berdasar refleksi siklus kedua

k) Melaksanakan pembinaan pada siklus ketiga

1) Melakukan observasi

m)Melakukan refleksi pada siklus ketiga

n) Menyusun laporan

\section{Siklus I}

Pelaksanaan kegiatan pembinaan untuk siklus 1 dilaksanakan pada tanggal 9 Januari - 18 Januari di SMP binaan Sub Rayon SMP N 41 Medan dengan jumlah 20 orang kepala SMP di Wilayah Binaan. Dalam hal ini peneliti bertindak sebagai pengawas. Adapun proses pembinaan mengacu pada rencana kepengawasan yang telah dipersiapkan.

Pengamatan (observasi)

dilaksanakan bersamaan dengan pelaksanaan pembinaan di sekolah. Pada akhir proses pembinaan kepala sekolah diberi tes formatif I dengan tujuan untuk mengetahui tingkat keberhasilan kepala sekolah dalam meningkatkan kinerjanya dalam menerapkan model penilaian hasil belajar sesuai dengan yang telah dilakukan.

Pembinaan yang dilakukan oleh pengawas melalui supervisi manajerial diperoleh nilai rata-rata peningkatan kinerja kepala sekolah adalah 64,25\% atau ada 9 kepala sekolah dari 20 orang sudah tuntas. Hasil tersebut menunjukkan bahwa pada siklus pertama secara kelompok kepala SMP belum meningkat kinerjanya, karena yang memperoleh nilai $\geq 65$ hanya sebesar $45 \%$ lebih kecil dari persentase ketuntasan yang dikehendaki yaitu sebesar $85 \%$. Hal ini disebabkan karena banyak kepala sekolah yang baru diangkat/dilantik menjadi kepala sekolah sehingga mereka merasa baru dengan tugas tersebut.

\section{Siklus II}

Pelaksanaan kegiatan pembinaan supervisi manajerial untuk siklus II dilaksanakan pada tanggal bulan Januari di SMP Binaan Pengawas di Kota. Dalam hal ini peneliti bertindak sebagai pengawas. Adapun proses pembinaan 
mengacu pada rencana pembinaan dengan memperhatikan revisi pada siklus I, sehingga kesalahan atau kekurangan pada siklus I tidak terulang lagi pada siklus II. Penelitian tindakan kepengawasan ini dilaksanakan sesuai dengan prosedur rencana pembinaan dan skenario kepengawasan.

Pada akhir proses pembinaan kepala sekolah diberi tes formatif II dengan tujuan untuk mengetahui tingkat keberhasilan kepala sekolah dalam meningkatkan kinerjanya. Instrumen yang digunakan adalah tes formatif II.

Dari hasil analisis siklus ke 2 nilai rata-rata peningkatan kinerja kepala sekolah adalah $73,75 \%$ dan peningkatkan kinerja mencapai $85 \%$ atau ada 17 kepala sekolah dari 20 orang sudah tuntas. Hasil tersebut menunjukkan bahwa pada siklus II ini peningkatan kinerja kepala sekolah telah mengalami peningkatan sedikit lebih baik dari siklus I. Adanya peningkatan kinerja kepala sekolah ini karena pengawas telah menginformasikan bahwa setiap akhir pembinaan akan diadakan penilaian sehingga pada pertemuan berikutnya kepala sekolah lebih termotivasi untuk meningkatkan kinerjanya. Selain itu kepala sekolah juga sudah mulai mengerti apa yang dimaksudkan dan diinginkan oleh pengawas dalam melakukan pembinaan supervisi akademik pengawas.

\section{Siklus III}

Pelaksanaan pembinaan untuk siklus III dilaksanakan pada bulan Februari dengan jumlah 20 orang kepala sekolah. Dalam hal ini peneliti bertindak sebagai pengawas. Adapun proses pembinaan mengacu pada rencana pembinaan dengan memperhatikan revisi pada siklus II, sehingga kesalahan atau kekurangan pada siklus II tidak terulang lagi pada siklus III. Pengamatan (observasi) dilaksanakan bersamaan dengan pelaksanaan tugas supervisi dan kepengawasan lainnya yang diberikan oleh Kepala Dinas Pendidikan Nasional Kota Medan.

Pada akhir proses pembinaan kepala sekolah diberi tes formatif III dengan tujuan untuk mengetahui tingkat keberhasilan kepala sekolah dalam meningkatkan kinerjanya yang telah dilakukan. Instrumen yang digunakan adalah tes formatif III.

Berdasarkan hasil tindakan siklus III diperoleh nilai rata-rata tes formatif sebesar $83,25 \%$ dan dari 20 kepala sekolah secara keseluruhan sudah mencapai ketuntasan dalam meningkatkan kinerjanya melaksanakan peran dan fungsinya. Maka secara kelompok ketuntasan telah mencapai 100\% (termasuk kategori tuntas). Hasil pada siklus III ini mengalami peningkatan lebih baik dari siklus II. Adanya peningkatan hasil pembinaan pada siklus III ini dipengaruhi oleh adanya peningkatan kemampuan pengawas dalam menerapkan 
pembinaan kepengawasan melalui supervisi akademik sehingga kepala sekolah menjadi lebih memahami tugasnya (peran dan fungsinya) sehingga dapat meningkatkan kinerjanya. Di samping itu ketuntasan ini juga dipengaruhi oleh kerjasama dari kepala sekolah dengan pengawas dalam merencanakan program kerja sekolahnya masing-masing.

\section{PEMBAHASAN}

Pembahasan hasil penelitian tindakan dapat dianalisis sebagai berikut:

1. Ketuntasan Hasil Pembinaan Kinerja Kepala Sekolah

2. Melalui hasil penelitian ini menunjukkan bahwa pembinaan melalui supervisi Akademik memiliki dampak positif dalam meningkatkan kinerja kepala sekolah dalam menerapkan model penilaian hasil belajar, hal ini dapat dilihat dari semakin mantapnya pemahaman kepala sekolah terhadap pembinaan yang disampaikan pengawas (Kinerja kepala sekolah meningkat dari siklus I, II dan III) yaitu masingmasing 64,25\%; 73,75\%; 83,25\%. Pada siklus III kinerja kepala sekolah dalam melaksanakan peran dan fungsinya secara kelompok dikatakan tuntas.

3. Kemampuan pengawas dalam meningkatkan kinerja kepala sekolah

4. Berdasarkan analisis data, diperoleh aktivitas kepala sekolah dalam meningkatkan kinerjanya dalam setiap siklus mengalami peningkatan. Hal ini berdampak positif terhadap kinerja kepala sekolah yaitu dapat ditunjukkan dengan meningkatnya nilai ratarata kepala sekolah pada setiap siklus yang terus mengalami peningkatan.

5. Aktivitas pengawas dan kepala sekolah dalam pembinaan melalui Supervisi Akademik.

Analisis data, diperoleh dari aktivitas pengawas dan kepala sekolah yang paling dominan dalam kegiatan supervisi akademik adalah bekerja dengan menggunakan alat/media, mendengarkan/memperhatikan

penjelasan pengawas, dan diskusi antar kepala sekolah dan pengawas. Jadi dapat dikatakan bahwa aktivitas kepala sekolah dapat dikategorikan aktif.

Sedangkan untuk aktivitas pengawas selama pembinaan telah melaksanakan langkah-langkah metode pembinaan melalui supervisi Akademik dengan baik. Hal ini terlihat dari aktivitas kepala sekolah yang muncul diantaranya aktivitas membuat dan merencanakan program sekolah, melaksanakan, memberi umpan balik/evaluasi/tanya jawab di mana prosentase untuk aktivitas di atas cukup besar.

Berdasarkan hasil penelitian di atas, peningkatan kinerja kepala sekolah melalui pembinaan supervisi Akademik hasilnya sangat baik. Hal itu tampak pada pertemuan pertama dari 20 orang kepala sekolah yang ada pada saat penelitian ini dilakukan nilai rata-rata mencapai ; 64,25\% meningkatkan menjadi $73,75 \%$ dan pada siklus 3 meningkatkan menjadi 83,25\%.

Dari analisis data di atas bahwa pembinaan kinerja pengawas melalui supervisi Akademik efektif diterapkan dalam upaya meningkatkan kinerja kepala sekolah, yang berarti proses pembinaan pengawas lebih berhasil dan 
dapat meningkatkan kinerja kepala sekolah khususnya kepala SMP di Kota Medan, oleh karena itu diharapkan kepada para pengawas dapat melaksanakan pembinaan melalui supervisi manajerial secara berkelanjutan.

Berdasarkan Permen No. 13

Tahun 2007 tentang kompetensi kepala sekolah, dan dapat membuat rencana kerja sekolah, serta dapat mengorganisasikan sekolah ke arah perubahan yang diinginkan mencapai $85 \%$ ketercapaiannya, maka kinerja kepala sekolah tersebut dikatakan efektif. Dengan demikian maka hipotesis yang diajukan di atas dapat diterima.

\section{KESIMPULAN}

Kesimpulkan penelitian tindakan pengawasan ini adalah sebagai berikut :

1. Dengan pembinaan pengawas dalam upaya meningkatkan kinerja kepala sekolah pada model penilaian hasil belajar dengan supervisi Akademik menunjukkan peningkatan pada tiap-tiap putaran (Siklus).

2. Seluruh kepala sekolah dapat meningkatkan kinerjanya dalam menerapkan model penilaian hasil belajar dengan baik dalam setiap aspek.

3. Peningkatan kinerja kepala sekolah dapat tercapai melalui siklus yang dilakukan pengawas.

4. Melalui supervisi Akademik bermanfaat dan dapat membantu kepala sekolah untuk lebih mudah memahami konsep penilaian hasil belajar oleh kepala sekolah sehingga kinerja kepala sekolah dapat meningkat.

\section{SARAN}

1. Program penilaian tindakan untuk mengembangkan alat ukur keberhasilan yang lebih reliabel agar dapat dilanjutkan dalam peningkatan kinerja kepala sekolah dengan baik sehingga mutu pendidikan dapat ditingkatkan.

2. Melalui supervisi Akademik dalam upaya meningkatkan kinerja kepala sekolah diperlukan secara berkelanjutan dengan dukungan pemerintah daerah.

3. Kepala sekolah diharapkan menguasai prinsip-prinsip rekontruksi evaluasi belajar melalui metode evaluasi belajar yang berkembang.

\section{DAFTAR PUSTAKA}

Arikunto, Suharsimi. 2004. Dasardasar Supervisi. Jakarta : Rineka Cipta.

Brookhart. Susan M. and Anthony, Nitko J. (2007). Educational Assesment of Student. Fifth Edition. New Jersey: Meril Prentice Hall.

Depdiknas RI. 2005. Peraturan Pemerintah No. 19 Tentang Standar Isi Pendidikan. Jakarta: Depdiknas.

Dirjen PMPTK, 2007. Peraturan Menteri No. 13 Tentang Standar Kompetensi Kepala Sekolah. Jakarta : Dirjen PMPTK Depdiknas.

Maxwell, John C (2001) Mengembangkan Kepemimpinan di sekeliling anda. Dialih bahasakan oleh Meiliana Purnama, Jakarta. PT. Mitra Media. 
Munandar, (1999) Manajemen Pendidikan, Mandar Maju, Bandung.

Nasution, S. (1988). Metode Penelitian Naturalistik Kualitatif. Bandung, Tarsito.
Samana. (1994). Profesionalisme Keguruan; Kompetensi dan Pengembangannya. Jogyakarta : Penerbit Kanisius (anggota IKAPI).

Pardede, L. (2019). MENINGKATKAN KOMPETENSI GURU DALAM MENYUSUN PERENCANAAN PEMBELAJARAN MELALUI BIMBINGAN

BERKELANJUTAN DI SMA NEGERI17 MEDAN. Jurnal Darma Agung, 27(1), 854 - 862 . Retrieved from https://jurnal.darmaagung.ac.id/i ndex.php/jurnaluda/article/view/ 141 